\title{
PHYLOGENETIC RELATIONSHIP OF PHYTOPHTHORA SP. INFECTED CITRUS IN EAST JAVA OF INDONESIA USING POLYMERASE CHAIN REACTION
}

\author{
Widyaningsih Sri*, Dwiastuti Mutia Erti \\ Indonesian Citrus and Subtropical Fruits Research Institute, Indonesia \\ ${ }^{*}$ E-mail: sri.wiwied74@gmail.com
}

\begin{abstract}
Soilborne Phytophthora species are the pathogen that causes several diseases on citrus in Indonesia. The objective of this research was to know phylogenetic relationship of Phytophthora sp. causing citrus crown rot disease in East Java Indonesia using Polymerase Chain Reaction. The research was carried out at Phytopathology Laboratory, Indonesian Citrus and Subtropical Fruits Research Institute (ICSFRI). The phylogenetic relationship analysis was based on PCR using ITS (Internal Transcribed Spacer) primer. In the research, 21 cultures of Phytophthora were isolated from infected citrus rootstock at citrus center production (Banyuwangi, Jember, Ponorogo, Blitar, and Tulungagung), 2 culture isolates from non citrus center production (Kraton-Pasuruan and Tlekung-Batu) and 1 culture isolate from apple rootstock infected by Phytophthora. The result showed that several isolates from Banyuwangi, Jember, Ponorogo, Blitar and Tulungagung have $100 \%$ similarity coefficient, while Banyuwangi-2 isolate have $82 \%$ similarity. Ponorogo isolates number 3,4 , and 5 have $100 \%$ similarity coefficient. That isolates with other 21 isolates have smallest similarity, i.e. $28 \%$. These data suggest that frequent outbreaks of Phytophthora crown rot in various citrus growing centers might be resulted from other factors rather than from different genetic structure, such as climatic condition which is conducive for the disease epidemic, resistance of citrus rootstock, and plant maintenance.
\end{abstract}

\section{KEY WORDS}

Citrus, disease, fungi, Phytophthora, variability.

Phytophthora causes the most serious soilborne disease of citrus in Indonesia. The pathogen can infect on all part of citrus, cause root rot, foot rot and gummosis on rootstock, damping off, leaf necrosis and fruit rot. The Phytopthora disease in Indonesia is quite evenly distributed and causes highest mortality after huanglongbing and diplodia diseases. Phytophthora sp. isolates have genetic variability and difficult to examine of the differences based on morphological characters. Conventional identification methods based on morphological characteristics using the microscope are tedious, require expertise, need more time and sometimes may lead to wrong identification. According to Burgess et al. (2009) saveral of the new taxa are closely related to species with similar morphology (e.g., P.sp.4 and $P$. citricola), but in some new taxa are morphologically indistinguishable from species such as $P$. citricola, $P$. drechsleri, and $P$. megasperma. Forster et al. (2000) state that the antheridial position together with homo- or heterothallic habit does not reflect phylogenetic relationships within Phytophthora because Phytophthora occurs convergent evolution.

Several molecular approaches are used for oomycetes identification such as isozyme analysis, Restriction Fragment Length Polymorphism (RFLP), Randomly Amplified Polymorphic DNA (RAPDs), Single-Strand-Confirmation Polymorphism of rDNA, and PCR of Internal Transcribed Spacer (ITS) (Foster et al., 1995, Ristaino et al., 1998, Kong et al., 2003, Cooke et al., 2000). The ITS coding regions have a critical role in the development of functional rRNA with sequence variations among species showing promise as signature regions for molecular assays, although not translated into proteins (Iwen et al., 2002). The ITS spacer region is being increasingly used as an important tool for classification and differentiation of bacterial species such as on genus Fusocaterium (Conrads et al., 2002). A recent study by a multinational and multilaboratory fungal barcoding consortium, the nuclear ribosomal internal transcribed spacer (ITS) has been selected as the DNA barcode for fungi. 
Identification organism at the species level was gain rapidly by DNA barcoding (Mahmoud and Zaher, 2015).

ITS-based Phytophthora identification system has more advantages compared to other methods since the ITS region of rDNA is well characterized. The rDNA evolves in a neutral manner at a rate which often approximates to the rate of speciation, and it has proven successful in distinguishing fungal taxa (Bruns et al., 1991; Lee and Taylor, 1992). These ITS regions are highly variable and can be used to distinguish and relate closely related organisms such as different species in the same genus. Recently, a molecular phylogeny of Phytophthora and related oomycetes was constructed based on the ITS sequences of rDNA (Cooke et al., 2000). Lee and Taylor (1992) published the ITS1 and ITS2 sequences of the tropical Phytophthora species P. palmivora, P. megakarya, $P$. capsici, $P$. citrophthora and $P$. cinnamomi and showed excellent resolution at the species level. According to Ippolito et al. (2004) effectiveness in the identification of $P$. nicotianae and $P$. citrophthora from citrus roots and soil between the molecular analysis uses traditional methods of isolation on selective media were compared using molecular procedures with DNA extraction and amplification showed the same results, although the traditional method requires a lot of time and expertise to identify both types of Phytophthora. At Texas, 22 isolates have been characterized using molecular methods, Polymerase Chain Reaction (PCR) with Ph2 and ITS4 primers resulted in a 700 base pair (bp) fragmen. This fragment was sequenced and a similarity search at GenBank showed $100 \%$ identity with P. nicotianae (Kunta et al., 2007). Genetic diversity among 16 isolates of $P$. palmivora obtained from diseased coconut plants showing nut fall disease were characterized by Random Amplified Polymorphic DNA (RAPD) using nine primers were highly different at 40.6 percent (Mutulo et al., 2007). On P. parasitica through this genomic approach and clustering analyses out of a total of 13,285 are available in the $P$. parasitica database, a group of 4,567 clusters was formed, comprising 2,649 singlets and 1,918 contigs. Out of a total of 4,567 possible genes, only 2,651 clusters were categorized; among them, only $4.3 \%$ shared sequence similarities with pathogenicity factors and defense (Rosa et al., 2007). The objective of this research was to know phylogenetic relationship of Phytophthora sp. causing citrus crown rot disease in East Java Indonesia using Polymerase Chain Reaction based on Internal Transcribed Spacer (ITS).

\section{MATERIALS AND METHODS OF RESEARCH}

Isolation and DNA Extraction. Isolation of pathogen used baiting technique (Erwin and Ribeiro, 1996) with lemons and apple fruit to isolate the fungus from soil, root and infected bark samples from citrus plantation in Indonesia i.e. Banyuwangi, Jember, Ponorogo, Blitar and Tulungagung districts, total 24 isolates on plates contain V8 medium. These plates were incubated at room temperature in the dark for a week. The colonies showing morphological characteristics of Phytophthora were observed under a microscope. This fungus was grown at $24{ }^{\circ} \mathrm{C}$ in a $10 \mathrm{ml}$ water culture for DNA extraction.

Similarity analysis was based on PCR technique with universal primer (White et al., 1990). DNA extraction use Goodwin et al. (1992) modified. Phytophthora sp. isolate, 6-10 days was transferred to V8 liquid medium in erlenmeyer. The miselium was harvested after 7-10 days, and filtered through Whatman No. 1 paper, then stored in eppendorf tubes. Then, mycelium crushed in liquid nitrogen and transferred to test tubes that had been given $1 \mathrm{ml}$ of buffer solution (1.4 M NaCl, $20 \mathrm{mM}$ EDTA, $100 \mathrm{mM}$ Tris-HCl (pH 8.0), 2\% (w / v) CTAB, 1\% ß-mercaptoethanol). Having crushed, the mixture was shaken until became homogeneous and incubated at $65^{\circ} \mathrm{C}$ for 30 minutes. RNAse $(10 \mathrm{ml})$ was added, shaken and then incubated for $1 \mathrm{~h}$ at $37^{\circ} \mathrm{C}$. After the chloroform and isoamil (24:1) was added with the same volume, it was shaken and centrifuged at $11.000 \mathrm{rpm}$ for 10 minutes. The liquid phase was transferred to new tubes and then was added to $1000 \mu \mathrm{l}$ chloroform, shaken and centrifuged at $11.000 \mathrm{rpm}$ for 10 minutes. Supernatant was removed and transferred to new tubes and added $1000 \mu \mathrm{l}$ cold isopropanol and shaken, then centrifuged at $11.000 \mathrm{rpm}$ for 10 minutes. Solution was discarded, DNA pellet then added with $200 \mathrm{ml}$ TE (1x), shaken gently and incubated for one hour at $37^{\circ} \mathrm{C}$. Then added 0.1 volume of sodium acetate and 2.5 volumes 
of absolute ethanol and centrifuged at $14.000 \mathrm{rpm}$ for 10 minutes. DNA pellet was washed with $500 \mathrm{ml} 70 \%$ ethanol and centrifuged at $12.000 \mathrm{rpm}$ at $4^{\circ} \mathrm{C}$ for 5 minutes. Ethanol was removed and the pellets were dissolved in $100 \mu \mathrm{l}$ TE at room temperature and stored at $20^{\circ} \mathrm{C}$.

DNA Amplification. Extracted DNA was amplified by PCR based on modified method of Trout et al. (1997) using the universal primers ITS 2, ITS 3, ITS4 and ITS 5. The primer pair of ITS 2 (5'-GCT GCG TTC TTC ATC GAT GC-'3), ITS 3 (5'-GCA TCG ATG AAG AAC GCA GC- '3), ITS 4 (5'-TCCTCCGCTTATTGATATGC -3 ') and ITS 5 (5'GGAAGTAAAAGTCGTAACAAG-3') (White et al., 1990). Amplification was performed in $25 \mathrm{ml}$ containing of: 10x PCR

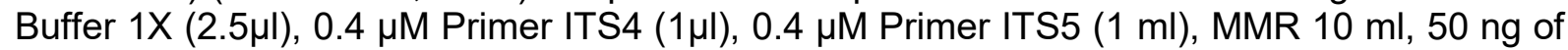
DNA samples $(2 \mathrm{ml})$, and ddH2O $(7 \mu \mathrm{l})$. The same composition made for the pair of ITS 5 and ITS 2, ITS 3 and ITS 4. DNA amplification using thermo cycler machine (Biometra) with the following thermal profile amplification, according to Trout et al., (1997) modified: initial denaturation at $94^{\circ} \mathrm{C}$ for 180 seconds, followed by 40 repeated cycles of melting, annealing and extention of DNA at $94^{\circ} \mathrm{C}$ for 60 seconds, $55^{\circ} \mathrm{C}$ for 60 seconds, $72^{\circ} \mathrm{C}$ for 120 seconds, respectively. In the last cycle, the extention step was increased to $10 \mathrm{~min}$. The PCR product were analysed by electroforesis on agarose gel $1 \%$, contain $10 \mathrm{mg} / \mathrm{ml}$ ethidiumbromide. Gel were documented by biodoc gel (Biometra).

Scoring and Dendogram Analysis. The scoring is based on the presence of DNA bands in each isolate. DNA bands formed from the results of molecular analysis that is considered as a character that represents a DNA locus. Then, DNA profiles are translated into binary data based on the presence of the band (1) and no DNA bands (0) to build a similarity matrix. Grouping of isolates on the UPGMA dendogram was calculated by using the program NTSys SHAN-PC version 2.10.

\section{RESULTS AND DISCUSSION}

Phytophthora isolates that used for analysis origin from crown rot disease at the centre of citrus plantation on East Java, Indonesia, i.e Banyuwangi ( 3 isolates), Jember (4 isolates), Ponorogo (5 isolates), Tulungagung (4 isolates), Tlekung (2 isolates), Kraton ( 1 isolate) and Blitar (4 isolates). Phytophthora isolate that used as comparison isolates origin from apple stem rot disease. Greening symptom of infected plant because root and trunk damage (Fig. 1). First visible symptomes in the root are dark, brown or black sunken areas, which quickly will enlarge. After the cortex is sloughed off often only the inner root strain is left. Above visible symptomes include leaf yellowing, wilting and leaf dropping. This is a result of the complete or partialy girdled trunk or by decreased root function cause root damage.

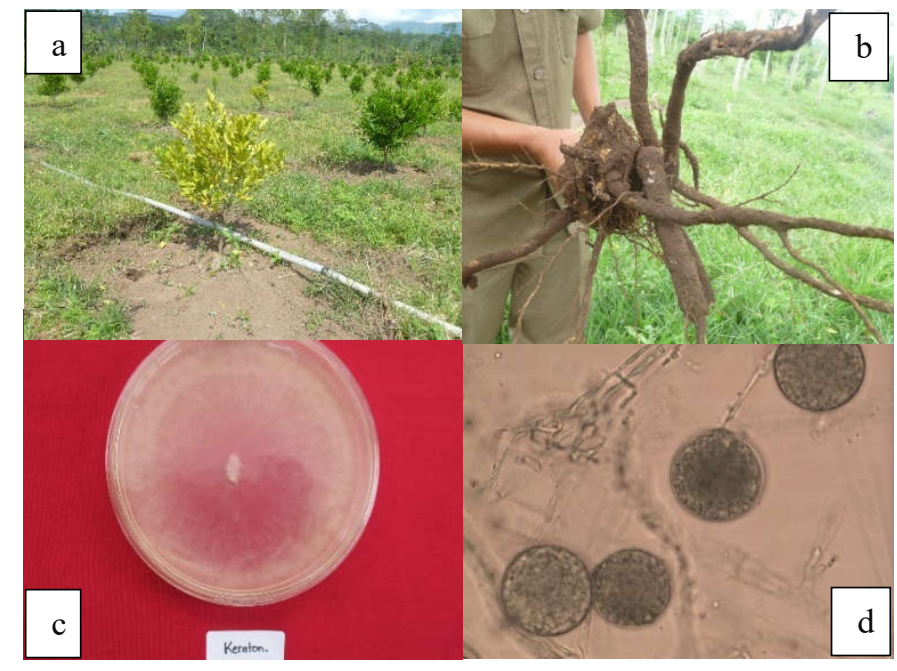

Figure 1 - Crown rot disease on citrus. (a). Symptom on infected plant, (b). rotting on stem and root, (c) An isolate of Phytopthora sp. from citrus, (d) One of character morphology of an isolate 
The results of electrophoresis showed that the genetic variability of Phytophthora sp. in citrus plantation is extremely wide. (Fig 2 and Fig 3).

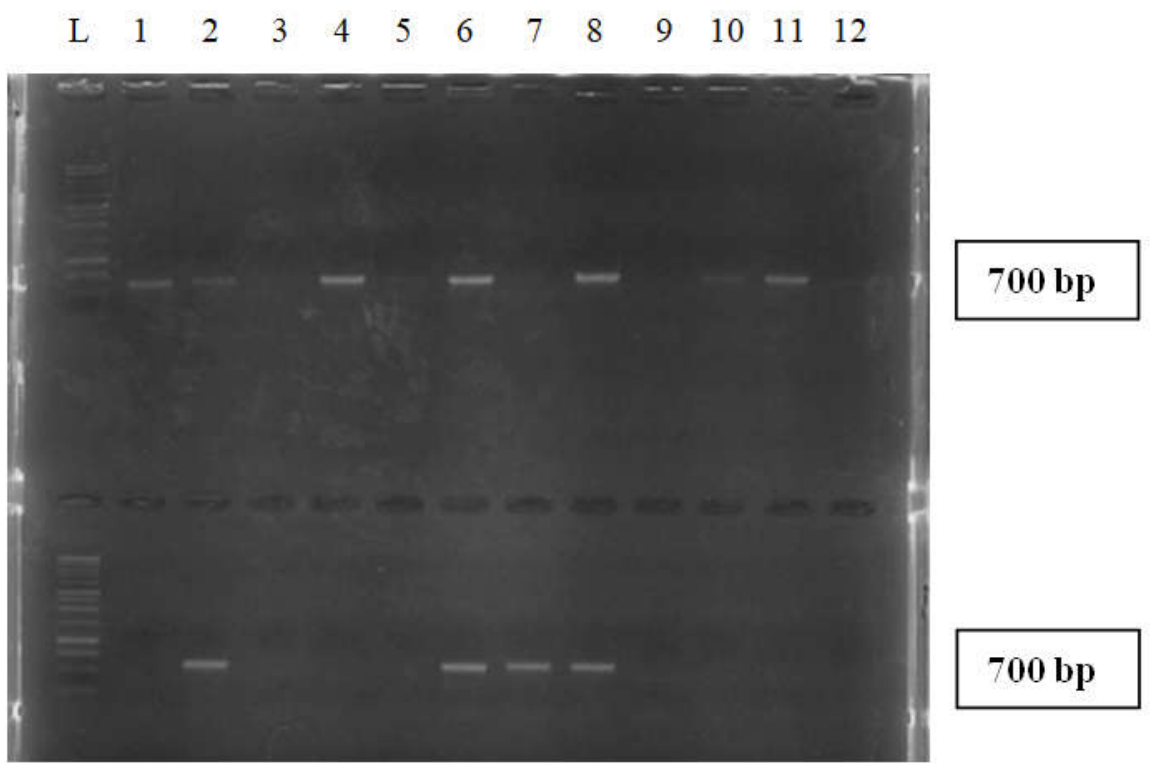

$\begin{array}{lllllllllllll}\text { L } & 13 & 14 & 15 & 16 & 17 & 18 & 19 & 20 & 21 & 22 & 23 & 24\end{array}$

Figure 2 - Amplification product of Phytophthora gene using ITS 5 and ITS 4 primer pairs L: DNA Leader $1 \mathrm{~kb}, 1-24$ : Phytophthora isolates

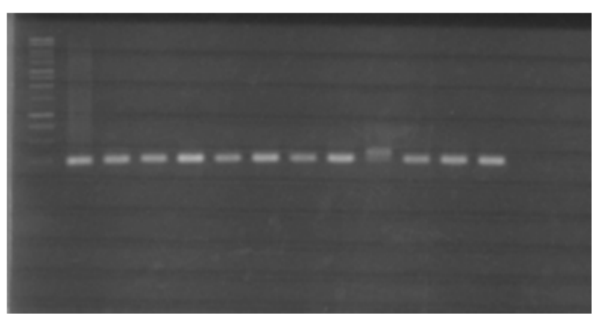

L $1 \begin{array}{llllllllllllll}1 & 2 & 3 & 4 & 5 & 6 & 7 & 8 & 9 & 10 & 11 & 12\end{array}$

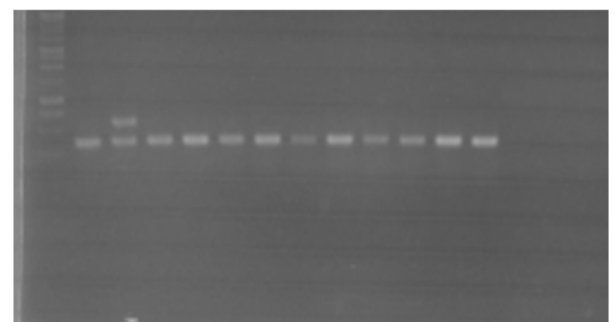

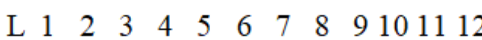

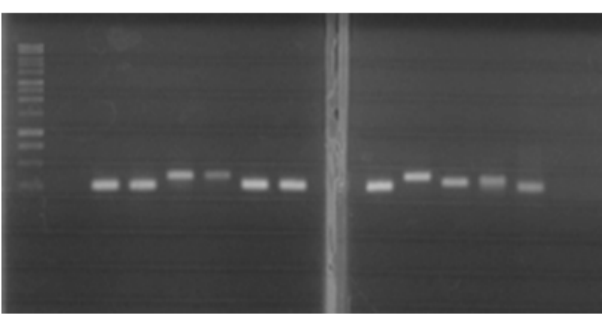

L $13141516171819 \quad 2021222324$

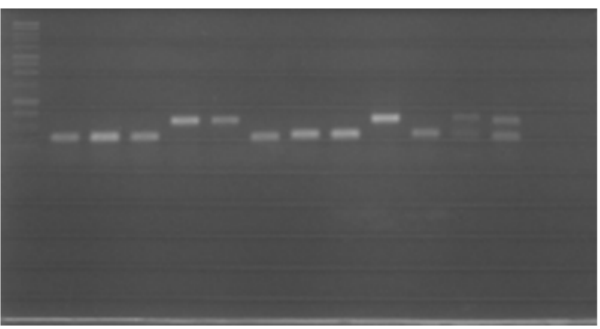

L 131415161718192021222324

Figure 3 - Amplification product of Phytophthora gene using ITS 5 and ITS 2 primer pairs (left), ITS 3 and ITS 4 primer pairs (right). L: DNA Leader $1 \mathrm{~kb}, 1-24$ : Phytophthora isolates

Phylogenetic analysis among all isolates of Phytophthora was based on the amplified fragments generated with the 3 pairs of primer, which was shown in a dendrogram (Fig. 4).

Dendogram showed that some isolates from Banyuwangi, Jember, Ponorogo, Blitar and Tulungagung have $100 \%$ similarity coefficient, that isolates with Banyuwangi 2 isolate has approximately $82 \%$ similarity. An isolates from Ponorogo number 3 , 4, and 5 have $100 \%$ similarity coefficient. These isolates with 21 other isolates have the smallest similarity $(28 \%)$. An isolate that was origin from apple stem rot have $78 \%$ compared to 6 isolates from citrus crown rot disease. 


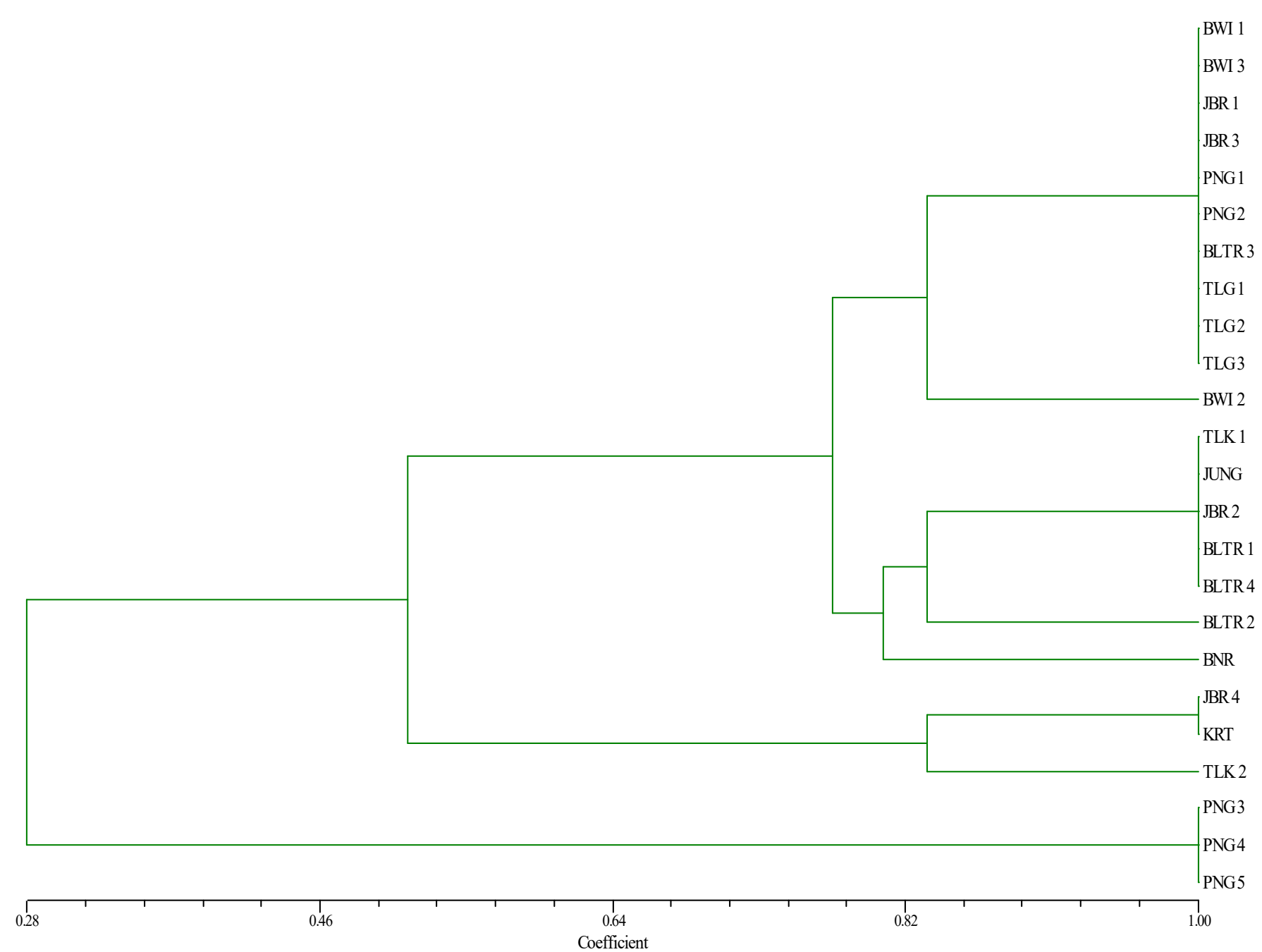

Figure 4 - Dendrogram showing the relationship among 23 Phytophthora isolates from citrus and 1 isolate Phytophthora from apel using 3 pairs primer ITS (Internal Transcribed Spacer). Origin of isolate: BWI (Banyuwangi); TLK (Tlekung); JBR (Jember); PNG (Ponorogo); TLG (Tulungagung); BLTR (Blitar); BNR (Banaran); KRT (Kraton). 
According to Kunta et al. (2007) P. nicotianae is the most prevalent species in Texas citrus plantation. In Brazil $P$. parasitica is pathogen that causes gummosis on citrus (Rosa et al., 2007). Base on this species, some researchers have concluded that these two names were being applied to a single species, the name of $P$. nicotianae earlier than $P$. parasitica. Often, Phytophthora are most closely related to an isolate origin from different island/country based on ITS, such as Phytophthora causing quick wilt of black peppers in Vietnam and Taiwan (Dung et al., 2014).

The impact of Phytophthora disease can be reduced through manipulation of the environment, such as by reducing humidity in orchards through pruning, weeding and good drainage. Crop rotation, sanitation (especially elimination of infected plant and soil) also provide good control. Planting resistant varieties will be the best option for controlling the disease. However, it is not available for all disease systems on citrus and against all species of Phytophthora. Contribution of genetic relationship of Phytophthora to spread of the disease do not know yet.

\section{CONCLUSION}

Phylogenetic relationship of Phytophthora sp. in East Java Indonesia citrus orchards are diverse and extremely wide Phytophthora crown rot might be resulted from other factors rather than from different genetic structure.

\section{REFERENCES}

1. Bruns, T.D., T.J. White, and J.W. Taylor. 1991. Fungal Molecular Systematics. Annu. Rev. Ecol. Syst. 22: 525-564.

2. Burgess, T. I., J.L. Webster, J.A. Ciampini, D. White, G. E. Stj. Hardy, and M.J.C. Stukely. 2009. Re-evaluation of Phytophthora species isolated during 30 years of vegetation health surveys in Western Australia using molecular techniques. Plant Dis. 93:215-22.

3. Cooke, D.E.L., A. Drenth, J.M. Duncan, G. Wagels, and C.M. Brasier .2000. A Molecular Phylogeny of Phytophthora and Related Oomycetes. Fungal. Genet. Biol. 30:17-32.

4. Conrads, G., M.C. Claros, D. M. Citron, K. L. Tyrrell, V. Merriam, and E.J.C. Goldstein. 2002. 16S-23S rDNA internal transcribed spacer sequences for analysis of the phylogenetic relationships among species of the genus Fusobacterium. Int. J. Syst. and Evo. Microb. 52: 493-499.

5. Dung, P.N., N. Tua, H.V. Cuong and M. Masaru. 2014. Analysis of internal transcribed spacer (ITS) region of Phytophthora tropicalis causing quick wilt disease of black pepper in Vietnam. Arch Phytopatology Plant Protect. 47(7): 842-851.

6. Erwin, D.C. and O.K. Ribeiro.1996. Phytophthora Diseases Worlwide. 562p. APS Press. St. Paul. Minn.

7. Foster, H., G. Learn, and M. D. Cojey. 1995. Towards a better understanding of the evolutionary history of the species of the genus Phytophthora using isozymes, DNA RFLP's, and rDNA spacer sequences. p. 42-54. In: L. J. Dowley, E. Bannon, L. R. Cooke, T. Keane, and E. O'Sullivan (eds.). Phytophthora 150. European Assn. for Potato Res., Boole, Ltd., Dublin, Ireland.

8. Forster, H., M.P. Cummings, and M.D. Coffey. 2000. Phylogenetic relationships of Phytophthora species based on ribosomal ITS I DNA sequence analysis with emphasis on Waterhouse groups V and VI. Mycol. Res, 104(9): 1055-1061.

9. Iwen, P.C., S. H. Hinrichs, and M. E. Rupp. 2002. Utilization of the internal transcribed spacer regions as molecular targets to detect and identify human fungal pathogens. Medical Mycology, 40:87-109.

10. Ippolito, A., L. Schena, F. Nigro, V.S. Ligorio, and T. Yaseen. 2004. Real-Time Detection of Phytophthora nicotianae and P. citrophthora in Citrus Roots and Soil. European Journal of Plant Pathol. 110: 833-843. 
11. Kong, P., C. Hong, P. A. Richardson, and M. E. Gallegly. 2003. Single-strandconformation polymorphism of ribosomal DNA for rapid species differentiation in genus Phytophthora. Fungal Genet. Biol. 39:238-249.

12. Kunta, M., Miao Hongqin, and Mani Skaria. 2007. Molecular Distinction of Citrus Phytophthora Isolates in the Lower Rio Grande Valley of Texas. Subtropical Plant Science, 59:1-5.

13. Lee, S. B. and J. W. Taylor. 1992. Phylogeny of five fungus-like protoctistan Phytophthora species, inferred from internal transcribed spacers of ribosomal DNA. Mol. Biol. Evolution. 9:636-653.

14. Mahmoud, A.G.Y and E.H.F. Zaher. 2015. Why Nuclear Ribosomal Internal Transcribed Spacer (ITS) has been Selected as the DNA Barcode for Fungi?. Adv Genet Eng, 4:119.

15. Motulo, H.F.J, M.S. Sinaga, S. Mandang, and Tjahjoleksono. 2004. Keragaman genetik beberapa isolat Phytophthora palmivora penyebab penyakit gugur buah pada kelapa berdasarkan penanda Random Amplified Polymorphic DNA (RAPD). Jurnal Penelitian Tanaman Industri, 10(4): 154-158.

16. Rohlf, FJ. 1993. NTSYS-pc: Numerical Taxonomy and Multivariate Analysis System. Applied Biostatistics Inc. New York

17. Ristaino, J.B., M. Madritch, C. L. Trout, and G. Parra.1998. PCR amplification of ribosomal DNA for species identification in the plant pathogen genus Phytophthora. Appl. Environ. Microbiol. 64:948-54.

18. Rosa, D.D., M.A. Campos, M.LP.N. Targon, and A.A. Souza. 2007. Phytophthora parasitica transcriptome, a new concept in the understanding of the citrus gummosis. Genet. Mol. Biol., 30(3): 997-1008.

19. Trout, C.L., J.B. Ristaino, M. Madritch, and T. Wangsomboonde. 1997. Rapid detection of Phytophthora infestans in late blight potatoes and tomatoes using PCR. Plant Dis. 81:1042-1048.

20. White, T.J., T. Bruns, S. Lee, and J.W. Taylor. 1990. Amplification and direct sequencing of fungal ribosomal RNA genes for phylogenetics. In PCR Protocol: A Guide to Methods and Applications, eds M.A. Innis, D.H. Gelfand, J.J. Sninsky, and T.J. White. Academic Pr Inc. New York. p. 315-322. 